\title{
Child Soldiers in Times of War: Issues Arising
}

\author{
Omodanisi Kemi Beatrice \\ Nigerian Institute of Advanced Legal Studies, University of Lagos Campus, Akoka, Yaba, Lagos State
}

\begin{abstract}
The recruitment and use of children as soldiers in war situation is an old phenomenon that has lingered over the years despite various international, regional and domestic laws prohibiting it. Baffling however are recent events that not only portray the use of children in war situation, but include their use for acts of terrorism which among other violations, violate their right to life. Other issues such as their criminal liability, the grant of refugee status, minimum age for criminal liability etc. have instigated several discourses from authors. The fact that recent events display the use of children for acts of terrorism raises an issue on whether the War on Terror prohibit and punish terrorists for engaging children. Relying on desktop materials, newspapers, statutory and judicial authorities this paper analyses this legal position. It further argues that though War on Terror as introduced by the United States of America after the wake of September 11, 2001 has been the medium for combating terrorism, recent happenings reveal that terrorism can be regulated by the Law of War which brings terrorist within the ambit of the Law that prohibits the use of children as soldiers and make them accountable for recruiting as well as using them for acts of terrorism.
\end{abstract}

Keywords: Child Soldiers, War on Terror, Terrorism, War

DOI: $10.7176 / \mathrm{JLPG} / 93-02$

Publication date: January $31^{\text {st }} 2020$

\section{Introduction}

Child Soldiering has remained an alarming global threat even with the existence of international, regional, and domestic legal frameworks prohibiting it. ${ }^{1}$

Child soldiers suffer untold hardship both as witnesses and perpetrators of crimes. They are used as fighters, spies, messengers and servants. Young girls recruited as soldiers are employed as sexual slaves exposed to rape, sexual abuse and harassment. ${ }^{2}$

With the wake of terrorism in most part of the world events have shown the use of children as perpetrators of terrorism. Terrorist groups such as Al Queda, Taliban fighters, Islamic State of Iraq and Sham (ISIS), Boko Haram etc. engage children in their activities. ${ }^{3}$ In addition, other than terrorist, some other groups especially during civil war in countries like Syria engaged children for combat e.g. the Free Syrian Army (FSA), Jabhat alNusra, Ahrar al-Sham, Syrian Kurdish groups etc. ${ }^{4}$ More so, during situation of conflict, children have been used as combatants especially in countries such as Liberia, Congo, Sierra Leone, Nigeria, Rwanda etc.

The continuous use of children over the years as soldiers has remained a topical issue and has raised several issues and opinions from various authors. As numerous as these issues are, this paper is only limited to key issues identified by the author. In light of recent use of children for acts of terrorism, this paper considers the extent to which the Law of War regulates terrorism for the sole purpose of prohibiting terrorist from recruiting and using children.

To this effect, this paper is divided into V Parts. Beside the introduction, the paper clarifies vital concepts and states the historical development of child soldiering in Part II. It also examines the Legal Framework prohibiting the recruitment and use of child soldiers. Part III considers the Use of Children as Soldiers, Part IV considers Issues arising from their recruitment and use. Lastly, Part V concludes and makes recommendation.

\section{Conceptual Clarification, Historical Development and Legal Framework Prohibiting Child Soldiering}

\subsection{Conceptual Clarification}

\subsubsection{Child}

A child means every human being below the age of eighteen years, unless under the law applicable to the child

\footnotetext{
${ }^{1}$ Egbe Olawari DJ, ' Book Review: Civil Wars, Child Soldiers and Post Conflict Peace Building in West Africa' ( 2014) 8 (2) African Research Review < http://www.ajol.info/index.php/afrrev/article/view/104284> accessed 18 June 2016.

${ }^{2}$ Abraham S, ' Child Soldier and the Capacity of the Optional Protocol to Protect Children in Conflict' Human Right Brief Online < https://www.wcl.american.edu/hrbrief/10/3abraham.pdf> accessed 18 June 2016.

${ }^{3}$ Ibid. ISIS has training centres where they train children as suicide bombers and fighters. See D Lizzie,' ISIS is Using Far More Child Soldiers Than the World Realised' Independent ( United Kingdom, 19 February, 2016) < www.independent.co.uk/news/world/middleeast/isis-using-more-child-fighters-than-feared-as-suicide-bombers-and-soldiers-after-brainwashing-at-a6883626.html $>$ accessed 29 August 2016.

4 Sommerfelt T and Taylor M B , 'The Big Dilemma of Small Soldiers: Recruiting Children to the War in Syria' (2015) Norwegian Peacebuilding Resource Centre Report, < http://reliefweb.int/sites/reliefweb.int/files/resources/f2c1eef2efb2c782b9a9dab621ceaf75.pdf > accessed 27 July 2016.
} 
majority is attained earlier. ${ }^{1}$ Black's Law Dictionary ${ }^{2}$ defines a child as a person under the age of majority.

Benotman and Malik $^{3}$ in defining a child noted that the age of a child determines his/her criminal responsibility and this is based on when the child is capable of committing a crime, standing trial and convicted for such crime.

\subsubsection{Child Soldier}

Cape Town Principles ${ }^{4}$ defines a Child Soldier as any person less than eighteen years of age who is part of any kind of regular or irregular force or armed group in any capacity, including but not limited to cooks, porters, messengers, and anyone accompanying such groups, other than family members. It further includes girls recruited for sexual purposes and for forced marriages.

\subsubsection{War}

Black's Law dictionary ${ }^{5}$ defines war as a hostile conflict by means of armed forces carried on between nations, states, rulers or sometimes between parties within the same nation or state. This definition applies basically to traditional war situation regarded as international armed conflict which arises between two or more High Contracting Parties to which International Humanitarian Law regulates. ${ }^{6}$ It also relates to non- international armed conflict which deals with internal conflicts of a state. ${ }^{7}$

Sassoli, Bouvier and Quintin ${ }^{8}$ opined that the traditional notion of war has been replaced since 1949 by the notion of armed conflict. They further opined that International Humanitarian Law (IHL) applies to acts of terrorism committed within the framework of an armed conflict. However, where acts of terrorism are committed in situations of internal violence or in time of peace, IHL do not cover such acts. ${ }^{9}$

\subsection{Historical Development}

Historically, child soldiers were first recruited and used during the Second World War; ${ }^{10}$ however, this was discouraged and diminished after the Second World War. ${ }^{11}$ This situation gained a different turn after the Cold War, where by as a result of the various internal, local, national, ethnic, and religious crisis, the recruitment and use of children as soldiers increased. ${ }^{12}$ As such, the fact that in contemporary times war is not limited to a clearly defined battlefield but extends to cities and towns has aided the abduction and recruitment of children from schools, villages, buses, farms etc. ${ }^{13}$ More so, the proliferation of small and light arms around the globe after the Cold War has also contributed to an increase in the use of child soldiers, considering that the size as well as the lightness of the weapons makes it easy for children to carry. Also, these weapons are relatively cheap, accessible and easy to operate.

In Nigeria, child soldiers were seen recruited and used during the 1967 Civil War. ${ }^{14}$ Initially, children below the age of eighteen were barely recruited as militias, however as the Civil War heightened children as young as Ten years were recruited by the Igbo Biafra force either as spies or as militias. ${ }^{15}$ In recent times, with the wake of terrorism and insurgency in Nigeria, particularly in the Northern part, Boko Haram have abducted children ( boys and girls) from schools, farms, villages, places of worship using them for various forms of vices. ${ }^{16}$

\footnotetext{
${ }^{1}$ Article 1 of the United Nations Convention on the Rights of the Child, Adopted and Opened for Signature, Ratification and Ascension by the General Assembly Resolution 44/25 of 20 November 1989 (entry into force 2 September 1990) < http://www.ohchr.org/Documents/ProfessionalInterest/crc.pdf $>$ accessed 25 July 2016. (hereinafter referred to as Convention on the Rights of the Child).

${ }^{2}$ Black's Law Dictionary, ( Eight edn, 1891-2004 ) ( Thomson West Publishing Co 2004).

${ }^{3}$ Benotman N and Malik N, 'The Children of Islamic State' ( 2016) Quilliam < https://www.quilliamfoundation.org/wp/wpcontent/uploads/publications/free/the-children-of-islamic-state.pdf $>$ accessed 29 August 2016.

${ }^{4}$ Cape Town Principles and Best Practices, adopted at the Symposium on the Prevention of Recruitment of Children into Armed Forces and on Demobilization and Social Reintegration of Child Soldiers in Africa, 27-30 April 1997, Cape Town, South Africa.< http://www.unicef.org/emerg/files/Cape_Town_Principles(1).pdf> accessed 23 July 2016.

${ }^{5}$ Black's Law Dictionary ( $\mathrm{n} 6$ ).

${ }^{6}$ That is the 1949 Four Geneva Conventions. Article 2(1) of Geneva Convention I-IV.

${ }^{7}$ Common Article 3 to the Four Geneva Convention of 1949, and Additional Protocol II.

${ }^{8}$ Sassoli B and Quintin, 'How Does Law Protect in War?' (2011) Vol 1 ICRC $<$ https://www.icrc.org/eng/assets/files/publications/icrc-0739part-i.pdf $>$ accessed 31 August 2016.

${ }^{9}$ Note that the War against Terror following the decision of the Supreme Court in Hamdan v. Rumsfeld 548 U.S 557 (2006) is recognized as a non-international armed conflict governed by common article 3 of the Geneva Convention. War against Terror was declared by United States of America after September 11, 2001 terrorist attack against Al-Qaeda. See D Glazier, "Playing by the Rules: Combating Al Qaeda within the Law of War" (2009) Vol 57 William and http://scholarship.law.wm.edu/cgi/viewcontent.cgi?article=1024\&context=wmlr $>$ accessed 31 August 2016.

${ }^{10}$ Colleen C M, 'The Protection of Children in Armed Conflict: A Human Rights Analysis of the Protection Afforded to Children in Warfare' (1989) B.C. Third World L.J 297.

11 Ibid.

${ }^{12}$ Abbott A B, 'Child soldiers-The use of Children as Instruments of War' (2000) 23 Suffolk Transnat'l L. Rev 499, 508.

${ }^{13}$ Ibid.

14 Egodi U, “ Recollection of Childhood Experiences During the Nigerian Civil War' (2007) < http://www.uky.edu/ clthyn2/PS439G/readings/uchendu_2007.pdf> accessed 26 July 2016.

${ }^{15}$ Ibid.

${ }^{16}$ Amnesty International, ‘ Nigeria: Boko Haram and Nigerian Military Committing Crimes Under International Law in North and East
} 


\subsection{Legal Frame Work Prohibiting the Use of Child Soldiers}

The legal regime prohibiting the use and recruitment of children as soldiers is codified in treaties, International Humanitarian Law, Customary International Law as well as in the law and practices of individual state.

Here, this paper considers some international, regional and domestic legal frame work that prohibits the recruitment and use of child soldiers.

\subsubsection{Convention on the Rights of the Child (CRC) ${ }^{1}$}

This document is a pioneer document that seeks to protect the right of a child. Together with its two optional protocols, which relates to the sale of children, child prostitution, child pornography, and the involvement of children in armed conflict, ${ }^{2}$ it categorically states the rights of a child. ${ }^{3} \mathrm{CRC}$ considers any person below the age of eighteen as a child, except if such attained majority earlier by virtue of the applicable law. ${ }^{4}$ It also prohibits children from been subjected to torture, other cruel, inhuman or degrading treatment or punishments such as capital punishment or life imprisonment without release. ${ }^{5}$ It further prohibits the unlawful or arbitral deprivation of the liberty or detention of a child except in accordance with the law. ${ }^{6}$

\subsubsection{Worst Forms of Child Labour Convention ${ }^{7}$}

This convention recognises a person under 18 years (eighteen) of age as a child ${ }^{8}$ and prohibits the compulsory or force recruitment of such child for the use of armed conflict. ${ }^{9}$ By this, each member state that ratifies the Convention shall take step to prohibit the recruitment of children as soldiers in armed conflict. ${ }^{10}$

2.3.3 Optional Protocol to the Convention on the Rights of the Child on the Involvement of Children in Armed Conflict ${ }^{11}$

This convention in its preamble noted that conscripting, enlisting or actively involving children under the age of 15 years (fifteen) in hostilities in both international and non-international armed conflicts amount to a war crime under the Rome Statute of the International Criminal Court. Additionally, it condemns with gravest concern the recruitment, training and use of children in hostilities within and across national borders by armed groups that is different from the armed forces of the state. ${ }^{12}$ Furthermore, it prohibits the compulsory recruitment of persons under 18 (eighteen) years of age into the armed forces of a state and mandates state parties to increase the minimum age requirement of persons who volunteers to join. ${ }^{13}$ However, state parties that permit the recruitment of persons under the age in its national armed force shall ensure that the recruitment is voluntary and with the consent of the child or legal guardian. Also, as a minimum requirement, the child should be fully aware of the duties involved in the military service and should present a reliable proof of age prior to the admission in the national military service. ${ }^{14}$ However, this exception is only available to the armed forces of a state, as other armed groups in a state are expressly prohibited from using persons under the age of $18 .{ }^{15}$

\subsubsection{African Charter on the Rights and Welfare of the Child ${ }^{16}$}

This Charter considers a child as persons below the age of 18. It prohibits state parties from recruiting children and encourages them to take measures prohibiting a child from taking direct part in hostilities. ${ }^{17}$

\footnotetext{
Nigeria'(2015) Amnesty International Written Statement to the $28^{\text {th }}$ Session of the UN Human Right Council $<$ http://www.refworld.org/pdfid/54eee0894.pdf> accessed 26 July 2016.

${ }^{1}$ Convention on the Rights of the Child (n 5).

${ }^{2}$ Optional Protocol to the Convention on the Rights of the Child on the Involvement of Children in armed conflict Adopted and Opened for signature, ratification and accession by General Armed resolution A/RES/54/264 of 25 May 2002 entered into force on 12 February 2002 . < http://www.unicef.org/gambia/Optional_Protocol_to_the_Convention_on_the_Rights_of_the_Child_on the_involvement_of_children_in_ar med_conflicts.pdf $>$ accessed 25 July 2016 .

${ }^{3}$ Begley Tracey B C , 'The Extraterritorial Obligation to Prevent the Use of Child Soldiers' (2012) 27(3) AM. U . Int'l L . Rev <

http://digitalcommons.wcl.american.edu/cgi/viewcontent.cgi?article=1799\&context=auilr $>$ accessed 25 July 2016.

${ }^{4}$ Article 1 of the Convention on the Rights of the Child.

${ }^{5}$ Article 37(a)

${ }^{6}$ Article 37 (b).

Worst Form of Child Labour Convention No. 182. Adopted on 17 June 1999 by the General Conference of the International Labour Organisation at its eighty- seventh session and was entered into Force on 19 December 2000 <http://un-act.org/wpcontent/uploads/2015/11/ILO-Worst-Forms-of-Child-Labour-Convention-1999-No.-1822.pdf> accessed 26 July 2016.

${ }^{8}$ Article 2, Worst Form of Child Labour Convention (1999) No. 182.

${ }^{9}$ Article 3(a), Worst Form of Child Labour Convention (1999) No. 182.

${ }^{10}$ Article 1, Worst Form of Child Labour Convention (1999) No. 182.

${ }^{11}$ Optional Protocol to the Convention on the Rights of the Child on the Involvement of Children in armed conflict (n 22).

12 Ibid. Preamble.

${ }^{13}$ Articles 2 and 3(1).

${ }^{14}$ Article 3(3) (a), (b) \& (c)

${ }^{15}$ Article 4(1).

${ }^{16}$ African Charter on the Rights and Welfare of the Child, adopted in Addis Ababa, Ethiopia, on 11 July 1990 , entered into force on 29 November 1999

${ }^{17}$ Article 22 (2).
} 


\subsubsection{The Rome Statute of the International Criminal Court ( ICC) ${ }^{1}$}

By the import of Article 26, the ICC is prohibited from having jurisdiction over any person under the age of eighteen (18) at the time of committing an alleged offence. Furthermore, it is a war crime to conscript or enlist children below the age of fifteen (15) by a country into the country's national armed force or engage them actively in hostilities. ${ }^{2}$

\subsubsection{Additional Protocols to the Geneva Conventions ${ }^{3}$}

Additional Protocols (Protocol I \& II) were the first international treaties that prohibited active participation of children in hostilities especially as regulated by IHL. ${ }^{4}$ Having recognized the age of fifteen (15) as the minimum age for recruiting and engaging children in armed conflicts, Additional Protocol I which relates to International Armed Conflict provides that priority shall be given to the oldest when recruiting children above the age of fifteen but below the age of eighteen. ${ }^{5}$ Furthermore, Additional Protocol II protects children below the age of fifteen (15) from being recruited by armed forces or groups in non-international armed conflicts. ${ }^{6}$

\subsubsection{Child's Right Act ${ }^{7}$}

By the import of Section 34 of the Act, children are prohibited from recruitment into the Armed forces of the Federal Republic of Nigeria. It further mandates the government and other agency or body to ensure that no child is directly involved in any military operation or hostilities. The Act considers any person under the age of eighteen years as a child. ${ }^{8}$

\subsection{The Use of Child Soldiers}

The use of child soldiers is one of the most disturbing and dangerous characteristics of modern day armed conflict considering that they are used by both state and non-state actors. ${ }^{9}$ As stated in the introduction of this paper, the use of child soldiers started way back after the Second World War, but has spread increasingly in contemporary times to various continents in nearly major armed conflicts in the world today. ${ }^{10}$ Current report suggests that children are used as soldiers in about twenty-five countries. ${ }^{11}$ Their active use is evident in countries like Sierra Leone, ${ }^{12}$ Liberia, ${ }^{13}$ Uganda,${ }^{14}$ Columbia, ${ }^{15}$ Myanmar, Congo Republic, Rwanda, Sudan, Southern Sudan, ${ }^{16}$ and Libya. ${ }^{17}$ This is not peculiar to Africa alone, the United Kingdom was also criticised for using children under the age of eighteen (18) to fight Israel and Iraq. ${ }^{18}$

\footnotetext{
1 Rome Statute of the International Criminal Court, July 17, 1998, 2187 U.N.T.S. 3 [hereinafter Rome Statute) < http://www.un.org/law/icc/index.html> accessed 1 September 2016.

11 Ursini B, 'Prosecuting Child Soldiers: The Call for an International Minimum Age of Criminal Responsibility,' (2016) 89 (2) St. John's Law Review <http://scholarship.law.stjohns.edu/cgi/viewcontent.cgi?article=6731\&context=lawreview> accessed 1 September 2016 ; Elizabeth F , 'Child Soldiers Still Used in More than 25 Countries around the World' The Washington Post (Washington, 14 March 2012)< https://www.washingtonpost.com/\%20blogs/blogpost/post/child-soldiers-still-used-in-more-than-25-countries-around-thewo\%20rld/2012/03/14/gIQAl2FNCS blog.html> accessed 1 September 2016.

12 Bald S H , 'Comment, Searching for a Lost Childhood: Will the Special Court of Sierra Leone Find Justice for Its Children?' (2002) 18 $A M$. U. Int'l l. Rev. 537, 552. Children were used by armed groups to commit most dangerous missions.

${ }^{13}$ Davison A, 'Child Soldiers: No Longer a Minor Incident' (2004), 12 Williamette J. Int'l l. \& disp. Resol. 124, 134. In Liberia when Charles Taylor seized power in 1997, his rebel army was mainly made up of youths, who he recruited by abduction and false promises. This was not peculiar to him alone as the rebel group who fought against him also made use of child soldiers. In fact, it is the UN 's estimation that 20,000 children served as combatants and constituted about 70 percent of various fighting forces in the country. See P W Singer, 'Books: 'Children at War', (The Washington Post, 12 June 2006) http://www.washingtonpost.com/wpdyn/content/discussion/2006/05/22/DI2006052200785.html accessed 1 September 2016. Here children as tender as nine years of age allegedly killed, tortured and raped victims.

${ }^{14}$ In Uganda, the Lord's Resistance Army of Northern Uganda was notorious for the abduction and recruiting of at least 20,000 children between 1987 and 2006; See Webster Timothy, 'Babes With Arms: International Law and Child Soldiers' (2007) 39 Geo. Wash. Int'L . Rev. $227,229$.

${ }^{15}$ It has been estimated by experts that the country has 5000 to 14,000 child soldiers. See Amy Lieberman, 'UN Security Council To Study Child Soldier Use in Colombia,' (2012) PASSBLUE <http://passblue.com/2012/06/28/un-security- council-to-study-child-soldier-use-incolombia/> accessed 1 September 2016.

${ }^{16}$ Elizabeth F ( n 48).

${ }^{17}$ Muammar Qaddafi and other rebel groups were recorded recruiting and using children below the age of eighteen (18). See Anthony Shadid, 'Libya's Youth Revolt Veers Toward Chaos', The New York Times, (Newyork 12 March 2011) $<$ http://www.nytimes.com/2011/03/13/world/africa/13opposition.html> accessed 1 September 2016.

${ }^{18}$ During the Iran-Iraq War in the 1980s, Iranian President Rafsanjanin asked all Iranians aged 12-72 to volunteer for the 'Holy War.' Many
} 
The recent use of children by terrorist has made the issue of child soldiering more alarming. Here many groups such as, IS, ${ }^{1}$ Al-Qaeda, Jabhat al-Nusra (JN), Free Syrian Army (FSA), Ashbal Saddam, ${ }^{2}$ Palestinian Islamic Jihad, Al-Shabaab, ${ }^{3}$ Boko Haram ${ }^{4}$ and so forth recruit children and adolescents. ${ }^{5}$ After recruiting them, these children are institutionalised in training camps were they undergo harsh combat, weapon training and indoctrinated socially and politically to perform the bids of these terrorist. ${ }^{6}$ These children apart from being taught how to make bombs are forced to watch videos of suicide bombings, after which they are sent to the front lines, where they function essentially as human shields, fighters, or as suicide bombers. ${ }^{7}$

Having seen this, the query is what is the rationale for conscripting children as soldiers?

To start with, children are readily available. ${ }^{8}$ They are cheaper compared to adults considering that they consume less food and require little or no remuneration as adults. Furthermore, children give more heed to orders, are easy to manipulate, exhibit unquestionable loyalty and commitment and are susceptible to easy indoctrination. ${ }^{9}$ More so, the fact that children are expendable and easy to replace at the event of death or injury make it convenient for recruiters to conscript them.

Additionally, considering that children most times are unable to evaluate the risk in fighting, they tend to be fearless and willing to fight. This explains why child soldiers are more susceptible to being killed than adult soldiers. ${ }^{10}$ More so, because of their tender nature, they provoke less suspicion and this makes it easy for recruiters to use them as spies and suicide bombers. ${ }^{11}$

In addition, poverty, starvation, unemployment and ethnic persecution have made children gullible and easily convinced to become soldiers. The prevalence of social factors as these make them willing to fight voluntarily for honour, duty, revenge, or for protection from violence. ${ }^{12}$

Furthermore, children voluntarily join armed conflicts in a bid to defend a particular cause they believe in, or fulfil a sense of communal belonging. ${ }^{13}$ Also, where there are financial benefits, children voluntarily enlist having been propelled by a need for survival as well as the need to support their families. ${ }^{14}$

Finally, some children who have lost their parents and love ones in the course of an armed conflict volunteer to join the military or other groups in a bid to get surrogate familial relationship. ${ }^{15}$

\subsection{Issues Arising from the Recruitment and Use of Child Soldiers}

The continuous use of children in international and non-international armed conflicts has raised issues which have lingered over time. This paper identifies and limits itself to the following.

4.1.1 Criminal Liability of Children as Soldiers- the question this issue raise is whether children who took part in international or non-international armed conflicts as soldiers can be held accountable for criminal offences under International Humanitarian Law? It is required that the child soldier possesses the criminal intent and knowledge to engage in the conduct. Such child should also mean to cause the consequence of the crime, or should be aware that the consequence will occur in the ordinary cause of event. Under International Criminal Law, the guilt of an accused person must be established, in other to make an offence punishable against such

children whose schooling were interrupted were sent to the frontlines with very little grenades. See P W Singer, 'The New Faces of War' (2005) American Educator <http://www.pwsinger.com/articles.html> accessed 1 September 2016. Also cited in Benotman N and Malik N (n 7).

${ }^{1}$ In 2015. the UN received a report of IS Youth wing known as 'Fityan Al Islam' (Boys of Islam) which train children for terrorism. See 'Report of the Secretary-General on Children and Armed Conflict in Iraq', United Nations Security Council, 9 November 2015, p. 9, $<$ http://www.un.org/ga/search/view doc.asp?symbol=S/2015/852\&Lang=E\&Area=UNDOC $>$ accessed 2 September 2016.

${ }^{2}$ Ashbal Saddam, also known as Saddam's Lion Cubs was founded after Iraq's defeat in the 1991 Gulf War as Saddam Hussein's attempt to reconsolidate his power. This group was notorious for recruiting boys aged 10 to 15 ; Benotman N and Malik N (n 7).

${ }^{3}$ This is an affiliate of Al-Qaeda in Somalia.

${ }^{4}$ In Nigeria, Boko Haram is famous for kidnapping, indoctrinate or force children to engage as suicide bombers. See Ludovico L, 'It's Not Just ISIS and Boko Haram, Child Soldier Recruitment is a Problem in Many Countries', International Business Times 24 October 2015 $<$ http://www.ibtimes.co.uk/focus-its-not-just-isis-boko-haram-child-soldier-recruitment- problem-many-countries-1525390 $>$ accessed 3 September 2016.

${ }^{5}$ Benotman N and Malik N (n 7).

${ }^{6}$ Ibid.

${ }^{7}$ Ibid.

${ }^{8}$ Sommers M , 'Children, Education and War: Reaching Education for All (EFA) Objectives in Countries Affected by Conflict' The World Bank, June 30, 2002, p. 5. <http://documents.worldbank.org/curated/en/2002/06/2002835/children-education-war- reaching-education-allefa-objectives-countries-affected-conflict $>$ accessed 3 September 2016.

${ }^{9}$ Benotman $\mathrm{N}$ and Malik N ( n 7).

${ }^{10}$ Schauer E \& E Thomas, ' The Psychological Impact of Child Soldiering' $(2010)<$ http://www.usip.org/sites/default/files/missingpeace/The \%20psychological\%20impact\%20of\%20child\%20soldiering\%20-\%20Schauer.pdf> accessed 10 August 2016.

${ }^{11}$ Ibid.

12 Ibid.

${ }^{13}$ Berti B \& A B Osete, 'Generational War: Syria's Children Caught Between Caught Between internal Conflict and the Rise of Islamic State' (2015) 18(3) Strategic Assessment

http://www.inss.org.il/uploadImages/systemFiles/adkan18_3ENG\%20\%284\%29_Berti\%20and\%20Osete.pdf> accessed 24 August 2016.

${ }^{14}$ Ibid.

15 Zack-Williams A B, 'Child Soldiers in the Civil War in Sierra Leone' (2001) 28 Rev. Afr. Pol. Econ. 78-79. 
person. ${ }^{1}$ How do you establish the guilt of a child soldier especially where he/she was coerced to commit a particular crime? In this situation, the required mens rea which is core in establishing the guilt of an accused within the ambit of International Criminal Law becomes absent. ${ }^{2}$

On this issue there are divergent views on establishing the culpability of child soldiers in war situation. Morss and Happold posit that children do not possess the special intent to commit genocide, crimes against humanity or war crime in that these crimes require a higher standard of mens rea that children cannot possibly possess. ${ }^{3}$ The rationale for their argument is premised on the fact that child soldiers mostly are coerced to commit a particular crime. In fact, most at times they are forced by the recruiters to rape, pillage and torture their family, friends and fellow citizens. ${ }^{4}$

On the contrary, Amnesty International opines that a child who voluntarily commits a punishable act for an army should be held accountable for his/her act. ${ }^{5}$ This flows from the fact that victims of such crime as well as the society require justice which a child soldier should be held accountable for. However, criminal actions against them must accord with international fair trial standards. ${ }^{6}$

Having seen these positions, this paper avers that child soldiers should not have absolute responsibility for their criminal acts; this is because they are more victims of criminal acts than perpetrators. Other than the fact that, their age limits them from recognizing the implication of their act, the coercion or threat to commit a particular crime robs them of the mental capacity to commit such crime. However, where a child is matured enough to understand the severity of his/her actions such child can be held liable criminally for his/her action. This accord with the provision of the Convention on Right of the Child which provides that young persons can be prosecuted in as much as the procedure is fair, in the best interest of the child with credence given to the vulnerability of the child. ${ }^{7}$

\subsubsection{Minimum age for Criminal Responsibility of Child Soldiers}

The Convention on the Right of the Child notably did not provide the minimum age for criminal liability of children. It however enjoins states parties to take steps to provide the minimum age below which children shall be presumed incapable of infringing penal laws. ${ }^{8}$ In a bid to conform to this provision, state parties in their domestic laws take steps to provide for such minimum age. However, there are discrepancies in these domestic legislations, as there is no uniform law on the minimum age of criminal liability for children. To illustrate this better, if for instance, a thirteen year old child from Congo is suspected of participating in genocide in Rwanda, since there is no international minimum age for criminal responsibility, either nation that assume jurisdiction over the child can apply her own minimum age for criminal responsibility. Rwanda which provides the age of fourteen ${ }^{9}$ for criminal responsibility might deem the child criminally responsible, unlike what is obtainable in Congo which provides for the age of thirteen. ${ }^{10}$ This discrepancy pictures a scenario where a child will be deemed culpable of committing an offence with requisite intent in a nation, where as in another nation same child will be deemed incapable. ${ }^{11}$

\subsubsection{Ambiguity on Whether Child Soldiers are Victims or Perpetrators of Crime}

It is important to note that as early as 1924 the vulnerability of children was recognised by international law. As such, steps were taken to afford them special rights and protection during armed conflict, ${ }^{12}$ though the protection afforded them was based on their vulnerability as a segment of the society and not as participants in war. In 1977 the two Additional Protocols to the Geneva Conventions specially addressed children as combatants and by the import of art 77 (1)-(3) of Additional Protocol I children should be protected and respected. They are protected against any form of indecent assault as well as their involvement in international armed conflict. Additional Protocol II extends this protection to non-international armed conflict such as civil wars. ${ }^{13}$ Other international

\footnotetext{
Nobert M, 'Children at War: The Criminal Responsibility of Child Soldiers' (2011) 3 Pace Int'l L. Rev. Online Companion < http://digitalcommons.pace.edu/cgi/viewcontent.cgi?article=1025\&context=pilronline $>$ accessed 1 August 2016.

2 Article 30 of the Rome Statute of 16 January 2002. It was entered into force on 1 July 2002 . < https://www.icccpi.int/nr/rdonlyres/ea9aeff7-5752-4f84-be94-0a655eb30e16/0/rome statute english.pdf $>$ accessed 1 August 2016.

${ }^{3}$ Morss J R, 'The Status of Child Offenders Under International Criminal Justice: Lessons from Sierra Leone' (2004) 9 DEAKIN L. REV. 213, 219; Matthew Happold, 'The Age of Criminal Responsibility in International Criminal Law' in Karin Arts \& Vesselin Popovski (eds), International Criminal Accountability and the Rights of Children (The Hague: T.M.C. Asser Press, 2006$)$ p 5.

${ }^{4}$ Nobert M (n 71)

5 Amnesty Int'l, 'Child Soldiers: Criminals or Victims?' (2000) < https://www.essex.ac.uk/armedcon/story_id/Child\%20soldiers\%20Criminals\%20or\%20Victims.pdf> accessed 21 July, 2016.

${ }^{6}$ International Standard for fair trial of child soldiers requires that as a priority the interest of the child must be paramount. More so, their special interest as well their vulnerability must be borne in mind. As such, emphasis is placed on the rehabilitation as well as the reintegration of the child into the society rather than punishment.

${ }^{7}$ Article 3 and 40 .

${ }^{8}$ Article 40(3)(a)

${ }^{9}$ Don Cipriani, Children's Rights and The Minimum Age of Criminal Responsibility: A Global Perspective (Ashgate 2009$) 105$.

10 Ibid.

${ }^{11}$ Ursini B ( n 48).

${ }^{12}$ Geraldine V 'The International Legal Protection of Children in Armed Conflicts' (1994) 43 Int'l \& Comp. L.Q. 809, 810-11.

${ }^{13}$ Article 4 (3) (c ).
} 
laws prohibiting child soldiering as already mentioned provide protection for children.

Despite provisions in international law condemning the use of child soldiers, the treatment of their conduct within the realm of international law is ambiguous. ${ }^{1}$ The ambiguity owes to the fact that though international law succinctly states that the recruitment of child soldiers violates international law, it is largely quiet on the liability of child soldiers when they violate international law as a result of their recruitment. ${ }^{2}$ Furthermore, the fact that child soldiers have been tried in domestic courts of some nations further aggravates this. ${ }^{3}$

Commenting on the import of Additional Protocol II on the liability of child soldiers, Happold argues that since Protocol II set the age of fifteen as the age for recruitment in armed forces, a child of fifteen years of age should not be held accountable for his actions. ${ }^{4}$ He further argues that the fact that Additional Protocol II made no mention of the criminal liability of child soldiers indicates that they are intended to be exonerated as they lack the requisite mental capacity to commit criminal offence. ${ }^{5}$

Argument such as this might have influenced the formation of the Special Court for Sierra Leone, that exclude jurisdiction of the court over persons under fifteen years of age at the time of committing an offence. ${ }^{6}$ Children above fifteen but below eighteen were to be treated with dignity and worth, giving cognisance to his or her young age and the desire to rehabilitate, reintegrate him or her into constructive role in the society, in accordance with human right standard particularly, the right of a child. ${ }^{7}$

Furthermore, commenting on the mental makeup of teenagers, Vereen noted that critical areas of the brain that is needful for making judgments and understanding complex concepts as safety and freedom are not developed until people are in their twenties. ${ }^{8}$ Judicial authorities have alluded to this, for instance in the American case of Roper v. Simmons ${ }^{9}$ and Eddings v. Oklahoma ${ }^{10}$ the Supreme Court stated that minors particularly those in their earlier years are less mature and responsible than adult. As such, their vulnerability as well as lack of control of their immediate surroundings explains why juveniles are likely to be forgiven for their failure to escape negative influences in their whole environment.

Having seen these positions, this paper posits that children should be considered as victims and not perpetrators of crime. The premise upon which this conclusion is drawn owes to the fact that children once recruited are subjected to brutal induction in a bid to harden them emotionally and this rob them of their free will. In fact, they are punished where they offer help or display feelings for others being abused. ${ }^{11}$ Their recruiters continuously beat them up and expose them to scenes of violence; this includes forcing them to kill some captives or their own family members. ${ }^{12}$ They are at times introduced to cannibalistic practices e.g. forcing them to drink the blood of those they killed so as to harden their hearts and make them bold. ${ }^{13}$ More so, they are also exposed to the use of drugs in a bid to harden them further as combatants.

\subsubsection{Whether Child Soldiers are entitled to Refugee Status}

This issue queries whether child soldiers who have committed or is suspected of committing war crimes, crimes against peace or crimes against humanity is entitled to refugee status in light of the express provision of Article $1 \mathrm{~F}$ of the Refugee Convention, ${ }^{14}$ which prevents states from granting refugee status to persons suspected of committing war crimes, crimes against humanity or crimes against peace. The article made no distinction between adults and children. ${ }^{15}$

On this issue, authors have varying positions. Kingsley argues that Article $1 \mathrm{~F}$ should never exclude children even though they have committed atrocities in that they should be viewed as victims rather than violators. ${ }^{16}$ In

\footnotetext{
1 Everett J C, 'The Battle Continues: Fighting for a More Child-Sensitive Approach to Asylum for Child Soldiers' (2009) 21 Fla. J. Int'l L. 285, 298-99.

${ }^{2}$ Lonegan B , Sinners or Saints: Child Soldiers and the Prosecutor Bar to Asylum after Negusie v. Holder ( 2011$) 31$ (1) Boston College Third World War Journal < http://lawdigitalcommons.bc.edu/cgi/viewcontent.cgi?article=1003\&context=twlj> accessed 10 August 2016 .

${ }^{3}$ For instance, popular opinion in Rwanda maintains that "if a child was able to kill, discriminate between two ethnic groups to decide who was a Hutu moderate and who wasn't, and was able to carry out murder in threat way, why should that child be considered differently from an adult?"; See C Reis, 'Trying the Future, Avenging the Past: The Implications of Prosecuting Children For Participating in Internal Armed Conflict' (1997) 28 Colum. Hum. Rts. L. Rev. 634-35.

${ }^{4}$ Happold M , 'Child Soldiers: Victims or Perpetrators?' ( 2008) 29 U. La Verne L. Rev. 67.

${ }^{5}$ Ibid. 73-74.

${ }^{6}$ U.N. Secretary- General, The Establishment of a Special Court for Sierra Leone: Rep. of the Secretary-General, 1, U.N. Doc. S/2000/915 (Oct. 4, 2000).

${ }^{7}$ Article 7(1) Statute of the Special Court for Sierra Leone, Jan. 16, 2002, 2178 U.N.T.

8 Vereen Don, 'Research Shows Consequences of Drug Abuse on the Teenage Brain' (2007) 14 (3) The Challenge

$<$ http://www.thechallenge.org/challenge_14_3.pdf $>$ accessed 2 September 2016.

9543 U.S. 551, 569-70 (2005).

${ }^{10} 455$ U.S. 104, 115-16 (1982). 132

${ }^{11}$ Lonegan B (n 85) 95.

${ }^{12}$ Machel Graca, 'Impact of Armed Conflict on Children', 34, transmitted by Note of the Secretary-General, U.N. Doc. A/ 51/306 (Aug. 26, 1996).

13 Ibid

${ }^{14}$ Convention Relating to the Status of Refugees, July 28, 195 1, 189 U.N.T.S. 150

${ }^{15}$ United Nations High Commissioner for Refugees, The Exclusion Clauses: Guidelines on their Application, December 1995

${ }^{16}$ Kingsley M N, 'Exclusions Under Article IF: Some Reflections on Context, Principles and Practice' (2000) 12 Int'l. J. Refugee L. 295, at
} 
same vein, Happold argues that recruiting child soldiers amount to a serious breach under international law and their compulsory conscription in armed conflict is regarded as a form of slavery or enslavement which amounts to persecution. ${ }^{1}$ However, to be accorded recognition under the Refugee Convention, persecution must be on the ground of race, religion, nationality, membership of a particular social or political group. ${ }^{2}$ Considering this, Happold posits that children who are about to be conscripted into the armed forces of a country or any other group have a well-grounded basis for fear of persecution on the basis of membership to a particular social group.

More so, a person who was formally a child soldier is also exposed to the risk of persecution, as they are hated for their involvement in the atrocities committed. ${ }^{3}$

Having seen these, this paper avers that the provision of Article 1F of the Refugee Convention should not be read to exclude children from refugee status even though they have committed atrocious acts. The basis of the writer's position flows from the argument in the aforementioned issues, in that child soldiers are not criminally liable for their actions, and should be considered as victims of crime committed. More so, the fact that they are coerced into committing such atrocious act serves as a key defence. Although it is doubtful if this might hold sway in light of the United State Supreme Court's decision in Fedorenko v. United States. ${ }^{4}$

\subsubsection{The Use of Children in Perpetrating acts of Terrorism}

This seems to be the most recent and contemporary issue child soldiers are faced with especially as recent happenings reveal their engagement and use especially as suicide bombers by terrorist groups.

In 2016, Police in Iraq apprehended a boy who was covered with an explosive belt around his waist. The child who was in tears claimed that he was kidnapped by ISIS and forced to blow up himself. ${ }^{5}$ In Iraq and Syria, ISIS latest strategy of perpetrating acts of terrorism is by using children as suicide bombers to stage various attacks. Still fresh is the March 25, 2016 bombing during a youth football match at a stadium south of Baghdad. ${ }^{6}$ The bomber who is aged 16 detonated his explosives as officials were handing the trophies to players after the tournament. This claimed the lives of 28 persons and about 60 persons who were injured. ${ }^{7}$

In Nigeria, Boko Haram engages children as young as eight years of age, mostly girls to detonate bombs in schools and market places. ${ }^{8}$ Some of these explosives are hidden in their clothes or in baskets, and some children are even unaware that they are carrying explosives only for it to detonate in an unsuspecting crowd. ${ }^{9}$ Some of these children, mostly girls were kidnapped in school, while hawking or working in farms in remote villages. ${ }^{10}$ The fact that they raise little suspicion makes them useful tools in the hands of terrorist. Note that apart from girls and women, boys are mostly used as suicide bombers.

An issue arising from this is, whether terrorist can be brought within the legal frame work of the Four (4) Geneva Convention of 1949 and the additional protocols of 1977 for the purpose of holding them accountable for the use of children in armed conflict? Furthermore, does the Law of War cover the concept of War on Terror? These are issues raised as a result of using children for acts of terrorism.

In a bid to discuss these germane issues, it is apposite to know that there are varying opinions on whether the Law of War can regulate terrorism. Some opinions are to the effect that the War on terror introduced by the United States after the terrorist attack of September 11, 2001 on the World trade centre and Pentagon is the appropriate framework for combating terrorism. ${ }^{11}$ Other writers posit that the Law of War do not apply to the same extent as they apply to the War on Terror based on the fact that the War on Terror is a special kind of war that does not accord with ordinary Laws of War as the Law of War is intended for inter- state wars and not against terrorist organisations. ${ }^{12}$ While other varying position is to the effect that though the Law of War applies,

308.

${ }^{1}$ Happold Matthew, 'Excluding Children from Refugee Status: Child Soldiers and Article 1F of the Refugee Convention' (2002) 17 (6) American University International Law Review < http://digitalcommons.wcl.american.edu/cgi/viewcontent.cgi?article=1229\&context=auilr $>$ accessed 15 August 2016.

${ }^{2}$ Article I(A) 2 of the Convention Relating to the Status of Refugees.

${ }^{3}$ Ibid.

${ }^{4} 449$ U.S. 490 (1981). Here, a denaturalization proceeding was successfully brought by the U.S. government against Fedorenko on the ground that, as a concentration camp guard during World War II, he took active part in the persecution of inmates. It was Fedorenko's argument that he acted under duress, the Supreme Court however ruled that duress was not an available defence.

${ }^{5}$ Osborne S, 'ISIS Child Suicide Bomber Stripped of Explosive Belt before Attack in Iraq' Independent August 22, 2016) < http://www.independent.co.uk/news/world/middle-east/isis-child-suicide-bomber-iraq-turkey-attack-bomb-terrorism-terror-bombinga7203261.html> accessed 8 September 2016.

${ }^{6}$ Ibid.

${ }^{7}$ Ibid.

${ }^{8}$ UNICEF, 'Boko Haram Attacks with Children Suicide Bombers' < http://www.aljazeera.com/news/2016/04/boko-haram-children-suicidebombers-160412093755915.html> accessed 8 September 2016.

${ }^{9}$ Ibid.

${ }^{10}$ Al Jazeera, 'Nigeria's Boko Haram Uses Child Soldiers' < http://www.aljazeera.com/news/africa/2013/11/nigeria-boko-haram-uses-childsoldiers-201311291435525502.html $>$ accessed 9 September 2016.

11 Posner E A, "Terrorism and the Laws of War" (2005) 5(2) Chicago Journal of International Law < http://chicagounbound.uchicago.edu/cgi/viewcontent.cgi?article=2762\&context=journal_articles $>$ accessed 10 September 2016 .

${ }^{12}$ Anderson A, 'Who Owns the Rules of War?' New York Times Mag 38 (New York, 13 April 2003). 
however its application is in a modified form. The basis of this argument is pursuant to the 1977 Additional Geneva Convention. By this Protocol terrorist are to be treated as other regular soldiers and punished for their crime. In fact, Posner argues that the Law of War should relate on the basis that some terrorist organisations are vast to be likened to states. Their power and organisation is portrayed by their political goals making it reasonable enough for a government and a terrorist organisation to be regulated by the Law of War. ${ }^{1}$

Having seen this, this paper argues that recent terrorist attack and operations indicates that they have become sophisticated and well organised to be seen as a state. The Syrian crisis that has lingered over the years is an example of how terrorism can escalate from a simple anti-government protest to a full scale civil war. This has escalated even beyond the borders of the country and have drawn international attention by the involvement of other countries such as United States, France, United Kingdom, Russia, Iran, Turkey, Saudi Arabia, Qatar, Jordan etc. ${ }^{2}$ Other rival alliances such as the National Coalition for Syrian Revolutionary and several opposition forces e.g. those supported by several Western and Gulf Arab State is indicative of several interests in the Syrian crisis. $^{3}$

As such, it is the writer's position that War on Terror should be defined within the ambit of Law of War so as to provide a legal basis for tackling the use of child soldiers by terrorist groups.

\subsection{Conclusion}

Children are vital to the development and sustenance of any country. Their innocence and naivety should be preserved and not exploited as a basis for perpetrating crime, acts of terrorism or as combatants in times of war. Issues discussed in this paper reveal that there are more implications involved in using children than their recruitment and use ordinarily envisage. Recent use of children as suicide bombers robs them of the most important fundamental human right they have, which is the right to life and more international as well as domestic actions should be taken to discourage this.

Considering the fact that child soldiering have lingered over the years and has aggravated despite various international, regional and domestic steps taken to put an end to it, this paper recommends the following based on the various issues raised.

1. Need for a uniform minimum age for imposing criminal liability for children involved in war. International as well as domestic steps should be taken to situate a uniform age for criminal liability for children. This will go a long way to allay the discrepancies as regarding the minimum age of imposing criminal liability on child soldiers.

2. Need for state parties as well as receiving host communities to take steps to receive child soldiers irrespective of the crime they might have committed. They should be pitied rather than castigated. This is owing to the fact that they do not commit crime based on their volition or free will.

3. States should take steps to provide programmes that will help rehabilitate and ensure the reintegration of child soldiers.

4. With the recent use of children as suicide bombers, terrorist groups who engage them should be accountable for their actions under the law regulating armed conflict. International and national measures should be taken where appropriate to dissuade such atrocious acts.

\section{References}

Abraham S, ' Child Soldier and the Capacity of the Optional Protocol to Protect Children in Conflict' Human Right Brief Online < https://www.wcl.american.edu/hrbrief/10/3abraham.pdf > accessed 18 June 2016.

Egbe Olawari D J, ' Book Review: Civil Wars, Child Soldiers and Post Conflict Peace Building in West Africa' ( 2014) 8 (2) African Research Review < http://www.ajol.info/index.php/afrrev/article/view/104284> accessed 18 June 2016.

Lizzie D,' ISIS is Using Far More Child Soldiers Than the World Realised' Independent ( United Kingdom, 19 February, 2016) < www.independent.co.uk/news/world/middle-east/isis-using-more-child-fighters-thanfeared-as-suicide-bombers-and-soldiers-after-brainwashing-at-a6883626.html $>$ accessed 29 August 2016.

Sommerfelt T and M B Taylor, 'The Big Dilemma of Small Soldiers: Recruiting Children to the War in Syria' (2015) Norwegian Peacebuilding Resource Centre Report, < http://reliefweb.int/sites/reliefweb.int/files/resources/f2c1eef2efb2c782b9a9dab621ceaf75.pdf > accessed 27 July 2016

United Nations Convention on the Rights of the Child, Adopted and Opened for Signature, Ratification and Ascension by the General Assembly Resolution 44/25 of 20 November 1989 (entry into force 2 September

\footnotetext{
${ }^{1}$ Posner E A (n 120).

${ }^{2}$ US in September 2014 led a coalition and launched air strikes inside Syria in a bid to degrade and ultimately destroy IS. A year later, Russia also started an air campaign that targeted "terrorists" in Syria.

${ }^{3}$ BBC News 'Syria: The Story of the Conflict,' Middle East (March 2016) <http://www.bbc.com/news/world-middle-east-26116868> accessed 10 September 2016.
} 
$1990)<$ http://www.ohchr.org/Documents/ProfessionalInterest/crc.pdf > accessed 25 July 2016.

Benotman N and N Malik, 'The Children of Islamic State' ( 2016) Quilliam < https://www.quilliamfoundation.org/wp/wp-content/uploads/publications/free/the-children-of-islamicstate.pdf $>$ accessed 29 August 2016.

Cape Town Principles and Best Practices, adopted at the Symposium on the Prevention of Recruitment of Children into Armed Forces and on Demobilization and Social Reintegration of Child Soldiers in Africa, 27-30 April 1997, Cape Town, South $\quad$ Africa. $<$ http://www.unicef.org/emerg/files/Cape_Town_Principles(1).pdf> accessed 23 July 2016.

Sassoli B and Quintin, 'How Does Law Protect in War?' (2011) Vol 1 ICRC < https://www.icrc.org/eng/assets/files/publications/icrc-0739-part-i.pdf> accessed 31 August 2016.

Glazier D, "Playing by the Rules: Combating Al Qaeda within the Law of War" (2009) Vol 57 William and Mary Law Review < http://scholarship.law.wm.edu/cgi/viewcontent.cgi?article=1024\&context=wmlr $>$ accessed 31 August 2016.

Colleen C M, 'The Protection of Children in Armed Conflict: A Human Rights Analysis of the Protection Afforded to Children in Warfare' (1989) B.C. Third World L.J 297.

Abbott A B, 'Child soldiers-The use of Children as Instruments of War' (2000) 23 Suffolk Transnat'l L. Rev 499, 508.

Egodi U, ' Recollection of Childhood Experiences During the Nigerian Civil War' (2007) < http://www.uky.edu/ clthyn2/PS439G/readings/uchendu_2007.pdf> accessed 26 July 2016.

Amnesty International, ' Nigeria: Boko Haram and Nigerian Military Committing Crimes Under International Law in North and East Nigeria'(2015) Amnesty International Written Statement to the $28^{\text {th }}$ Session of the UN Human Right Council < http://www.refworld.org/pdfid/54eee0894.pdf> accessed 26 July 2016.

Optional Protocol to the Convention on the Rights of the Child on the Involvement of Children in armed conflict Adopted and Opened for signature, ratification and accession by General Armed resolution A/RES/54/264 of 25 May 2002 entered into force on 12 February $2002 .<$ http://www.unicef.org/gambia/Optional_Protocol_to_the_Convention_on_the_Rights_of_the_Child_on_the involvement_of_children_in_armed_conflicts.pdf $>$ accessed 25 July 2016.

Begley Tracey B C, 'The Extraterritorial Obligation to Prevent the Use of Child Soldiers' (2012) 27(3) AM. U. Int'l L . Rev < http://digitalcommons.wcl.american.edu/cgi/viewcontent.cgi?article=1799\&context=auilr $>$ accessed 25 July 2016.

Worst Form of Child Labour Convention No. 182. Adopted on 17 June 1999 by the General Conference of the International Labour Organisation at its eighty- seventh session and was entered into Force on 19 December $2000<\mathrm{http}$ //un-act.org/wp-content/uploads/2015/11/ILO-Worst-Forms-of-Child-Labour-Convention-1999No.-1822.pdf $>$ accessed 26 July 2016.

Rome Statute of the International Criminal Court, July 17, 1998, 2187 U.N.T.S. $3<$ http://www.un.org/law/icc/index.html> accessed 1 September 2016.

Additional Protocols to the 1949 Geneva Convention, dated 10 June 1977 . < https://treaties.un.org/doc/publication/unts/volume\%201125/volume-1125-i-17512-english.pdf> accessed 1 September 2016.

Topa I ,"Prohibition of Child Soldiering- International Legislation and Prosecution of Perpetrators" (2007) 3 (1) HanseLR < http://www.hanselawreview.org/pdf5/Vol3No1Art06.pdf> accessed 1 September 2016.

Ursini B, 'Prosecuting Child Soldiers: The Call for an International Minimum Age of Criminal Responsibility,' (2016) 89 (2) St. John's Law $<$ http://scholarship.law.stjohns.edu/cgi/viewcontent.cgi?article=6731\&context=lawreview $>$ accessed 1 September 2016

Elizabeth F, 'Child Soldiers Still Used in More than 25 Countries around the World' TheWashington Post (Washington, 14 March 2012)< https:/www.washingtonpost.com/\%20blogs/blogpost/post/child-soldiersstill-used-in-more-than-25-countries-around-the-wo\%20rld/2012/03/14/gIQAl2FNCS_blog.html > accessed 1 September 2016.

Bald S H , 'Comment, Searching for a Lost Childhood: Will the Special Court of Sierra Leone Find Justice for Its Children?' (2002) 18 AM. U. Int'l l. Rev. 537, 552.

Davison A, 'Child Soldiers: No Longer a Minor Incident' (2004), 12 Williamette J. Int'l l. \& disp. Resol. 124, 134.

Singer P W, 'Books: 'Children at War', (The Washington Post, 12 June 2006) http://www.washingtonpost.com/wp-dyn/content/discussion/2006/05/22/DI2006052200785.html accessed 1 September 2016.

Webster Timothy, 'Babes With Arms: International Law and Child Soldiers' (2007) 39 Geo. Wash. Int'L. Rev. 227, 229.

Amy Lieberman, 'UN Security Council To Study Child Soldier Use in Colombia,' (2012) PASSBLUE 
$<$ http://passblue.com/2012/06/28/un-security- council-to-study-child-soldier-use-in-colombia/> accessed 1 September 2016.

Anthony Shadid, 'Libya's Youth Revolt Veers Toward Chaos', The New York Times, (Newyork 12 March 2011) $<$ http://www.nytimes.com/2011/03/13/world/africa/13opposition.html> accessed 1 September 2016.

Singer P W, 'The New Faces of War' (2005) American Educator <http://www.pwsinger.com/articles.html $>$ accessed 1 September 2016.

'Report of the Secretary-General on Children and Armed Conflict in Iraq', United Nations Security Council, 9 November

2015 , p. $<$ http://www.un.org/ga/search/view_doc.asp?symbol=S/2015/852\&Lang=E\&Area=UNDOC $>$ accessed 2 September 2016.

Ludovico L, 'It's Not Just ISIS and Boko Haram, Child Soldier Recruitment is a Problem in Many Countries', International Business Times 24 October $2015<\mathrm{http}$ //www.ibtimes.co.uk/focus-its-not-just-isis-bokoharam-child-soldier-recruitment- problem-many-countries-1525390> accessed 3 September 2016.

Sommers M , 'Children, Education and War: Reaching Education for All (EFA) Objectives in Countries Affected by Conflict' The World Bank, June 30, 2002, p. 5 . $<$ http://documents.worldbank.org/curated/en/2002/06/2002835/children-education-war- reaching-educationall-efa-objectives-countries-affected-conflict> accessed 3 September 2016.

Schauer E \& E Thomas, ' The Psychological Impact of Child Soldiering' (2010) < http://www.usip.org/sites/default/files/missing-

peace/The $\% 20$ psychological $\% 20$ impact $\% 20$ of $\% 20$ child $\% 20$ soldiering\%20-\%20Schauer.pdf $>$ accessed 10 August 2016.

Berti B \& A B Osete, 'Generational War: Syria’s Children Caught Between Caught Between internal Conflict and the Rise of Islamic State' (2015) 18(3) Strategic Assessment < http://www.inss.org.il/uploadImages/systemFiles/adkan18_3ENG\%20\%284\%29_Berti\%20and\%20Osete.p df $>$ accessed 24 August 2016.

Zack-Williams A B, 'Child Soldiers in the Civil War in Sierra Leone' (2001) 28 Rev. Afr. Pol. Econ. 78-79.

Nobert M, 'Children at War: The Criminal Responsibility of Child Soldiers' (2011) 3 Pace Int'l L. Rev. Online Companion $<\mathrm{http}: / /$ digitalcommons.pace.edu/cgi/viewcontent.cgi?article=1025\&context=pilronline $>$ accessed 1 August 2016.

Article 30 of the Rome Statute of 16 January 2002. It was entered into force on 1 July $2002 .<$ https://www.icccpi.int/nr/rdonlyres/ea9aeff7-5752-4f84-be94-0a655eb30e16/0/rome_statute_english.pdf $>\quad$ accessed 1 August 2016.

Morss J R , 'The Status of Child Offenders Under International Criminal Justice: Lessons from Sierra Leone' (2004) 9 DEAKIN L. REV. 213, 219; Matthew Happold, 'The Age of Criminal Responsibility in International Criminal Law' in Karin Arts \& Vesselin Popovski (eds), International Criminal Accountability and the Rights of Children (The Hague: T.M.C. Asser Press, 2006) p 5.

Amnesty Int'l, 'Child Soldiers: Criminals or Victims?' (2000) < https://www.essex.ac.uk/armedcon/story_id/Child\%20soldiers-\%20Criminals\%20or\%20Victims.pdf> accessed 21 July, 2016.

Don Cipriani, Children's Rights and The Minimum Age of Criminal Responsibility: A Global Perspective (Ashgate 2009) 105

Geraldine V B 'The International Legal Protection of Children in Armed Conflicts' (1994) 43 Int'l \& Comp. L.Q. $809,810-11$.

Everett J C, 'The Battle Continues: Fighting for a More Child-Sensitive Approach to Asylum for Child Soldiers' (2009) 21 Fla. J. Int'l L. 285, 298-99.

Lonegan B,' Sinners or Saints: Child Soldiers and the Prosecutor Bar to Asylum after Negusie v. Holder ( 2011) 31 (1) Boston College Third World War Journal < http://lawdigitalcommons.bc.edu/cgi/viewcontent.cgi?article $=1003 \&$ context $=t w l j>$ accessed 10 August 2016.

Reis C, 'Trying the Future, Avenging the Past: The Implications of Prosecuting Children For Participating in Internal Armed Conflict' (1997) 28 Colum. Hum. Rts. L. Rev. 634-35.

Happold M, 'Child Soldiers: Victims or Perpetrators?' ( 2008) 29 U. La Verne L. Rev. 67.

Ibid. 73-74.

U.N. Secretary- General, The Establishment of a Special Court for Sierra Leone: Rep. of the Secretary-General, 1, U.N. Doc. S/2000/915 (Oct. 4, 2000).

Vereen Don, 'Research Shows Consequences of Drug Abuse on the Teenage Brain' (2007) 14 (3) The Challenge $<$ http://www.thechallenge.org/challenge_14 3.pdf $>$ accessed 2 September 2016.

Machel Graca, 'Impact of Armed Conflict on Children', 34, transmitted by Note of the Secretary-General, U.N. Doc. A/ 51/306 (Aug. 26, 1996). 
United Nations High Commissioner for Refugees, The Exclusion Clauses: Guidelines on their Application, December 1995.M N Kingsley, 'Exclusions Under Article IF: Some Reflections on Context, Principles and Practice' (2000) 12 Int'l. J. Refugee L. 295, at 308.

Happold Matthew, 'Excluding Children from Refugee Status: Child Soldiers and Article 1F of the Refugee Convention' (2002) $17 \quad$ (6) American University International Law Review < http://digitalcommons.wcl.american.edu/cgi/viewcontent.cgi?article=1229\&context=auilr $>$ accessed 15 August 2016.

Osborne S, 'ISIS Child Suicide Bomber Stripped of Explosive Belt before Attack in Iraq' Independent August 22, 2016) < http://www.independent.co.uk/news/world/middle-east/isis-child-suicide-bomber-iraq-turkeyattack-bomb-terrorism-terror-bombing-a7203261.html> accessed 8 September 2016.

UNICEF, 'Boko Haram Attacks with Children Suicide Bombers' < http://www.aljazeera.com/news/2016/04/boko-haram-children-suicide-bombers-160412093755915.html> accessed 8 September 2016.

Al Jazeera, 'Nigeria's Boko Haram Uses Child Soldiers' < http://www.aljazeera.com/news/africa/2013/11/nigeria-boko-haram-uses-child-soldiers$201311291435525502 . h t m l>$ accessed 9 September 2016.

Posner E A, "Terrorism and the Laws of War" (2005) 5(2) Chicago Journal of International Law < http://chicagounbound.uchicago.edu/cgi/viewcontent.cgi?article=2762\&context=journal_articles $>$ accessed 10 September 2016.

Anderson A, 'Who Owns the Rules of War?' New York Times Mag 38 (New York, 13 April 2003).

BBC News 'Syria: The Story of the Conflict,' Middle East (March 2016) <http://www.bbc.com/news/worldmiddle-east-26116868> accessed 10 September 2016.

Biography of Author

Omodanisi Kemi Beatrice is a Research Fellow with the Nigerian Institute of Advanced Legal Studies, University of Lagos. She holds a Bachelor of Law from University of Jos, Nigeria, a Masters of Law from University of Lagos, Nigeria and currently a $\mathrm{PhD}$ student at the University of Ibadan, Nigeria. Her area of interest is International Law. 